\title{
POSITIVITY OF EXoU GENE OF TYPE III SECRETION SYSTEM AND FLUOROQUINOLONE RESISTANCE OF Psedomonas aeruginosa FROM SPUTUM OF NOSOCOMIAL PNEUMONIA PATIENTS IN SANGLAH HOSPITAL, BALI
}

\author{
I Wayan Agus Gede Manik Saputra ${ }^{1,2}$, Ni Made Mertaniasih ${ }^{3}$, Ni Nengah Dwi Fatmawati ${ }^{4}$ \\ ${ }^{1}$ Bali Provincial Health Office, Bali Indonesia, ${ }^{2}$ Clinical Microbiology Study Programme, Faculty of Medicine, \\ Universitas Airlangga, Surabaya, ${ }^{3}$ Department of Medical Microbiology, Faculty of Medicine Universitas Airlangga, \\ Soetomo Hospital, Surabaya Indonesia, ${ }^{4}$ Department of Clinical Microbiology, Faculty of Medicine and Health Science, \\ Udayana University, Sanglah General Hospital, Bali, Indonesia
}

\begin{abstract}
ABSTRAK
Pseudomonas aeruginosa adalah salah satu bakteri Gram-negatif batang penyebab tersering pneumonia nosokomial. Exoenzyme U( ExoU) merupakan salah satu protein efektor paling virulen pada TTSS P. aeruginosa yang memiliki aktivitas phospholipase A2 poten dan paling berperan pada kerusakan jaringan paru pada pneumonia. Fluoroquinolone merupakan salah satu antibiotika yang memiliki aktivitas terhadap P. aeruginosa dan mengalami peningkatan resistensi sebanyak tiga kali lipat dalam dekade terakhir. Infeksi yang disebabkan oleh $P$. aeruginosa dengan fluoroquinolone resisten dan regio gen ExoU positif akan memiliki outcome klinis yang buruk. Penelitian ini bertujuan untuk mengetahui positivitas regio gen ExoU TTSS P. aeruginosa dan resistensi fluoroquinolone pada isolat klinik dari sputum pasien pneumonia nosokomial di RSUP Sanglah Denpasar. Isolat P. aeruginosa yang berasal dari sputum pasien pneumonia nosokomial yang telah diidentifikasi secara fenotif menggunakan Vitek2 Compact system (bioMérieux, Inc., Marcy-l'Etoile - France) kemudian dilanjutkan secara genotif menggunakan metode PCR. Uji resistensi isolat P. aeruginosa terhadap Ciprofloxacin diperoleh dari hasil uji sensitivitas pada alat Vitek2 Compact sedangkan regio gen ExoU sebagai penyandi protein efektor ExoU dideteksi melalui metode PCR. Dari 53 isolat P. aeruginosa, sebanyak 35 isolat (66,1\%) memiliki regio gen ExoU dan 22 isolat (41,5\%) resisten terhadap Ciprofloxacin. Berdasarkan tipe pneumonia nosokomial, proporsi isolat dengan genotif ExoU+ dan Ciprofloxacin resisten didapatkan pada kelompok VAP yaitu 57,1\% dan 54,5\%. Analisis korelasi menggunakan Chi square pada resistensi Ciprofloxacin dan regio gen ExoU menunjukkan adanya hubungan yang signifikan $(p=0,001)$. Sebagai simpulan, positivitas isolat dengan genotif ExoU+ lebih banyak ditemukan pada kelompok ciprofloxacin resisten. (FMI 2018;54:129-135)
\end{abstract}

Kata kunci: Pseudomonas aeruginosa; fluoroquinolone; ExoU; pneumonia nosokomial; isolat klinik sputum

\begin{abstract}
Pseudomonas aeruginosa is one of the Gram-negative rods bacteria that frequently cause nosocomial pneumonia. One of the main virulent effector proteins on Type III secretion system (TTSS) of P. aeruginosa is Exoenzyme U ( ExoU). ExoU works as a phospholipase A2 activity and exhibits lung tissue injury effect in pneumonia. As an antibiotic that has activity against $P$. aeruginosa, fluoroquinolone resistance has increased as many as three fold since the last decade. Infections caused by P. aeruginosa that are fluoroquinolone resistant and positive for ExoU gene show worse clinical outcome. The aim of this study was to determine the positivity of ExoU gene TTSS and fluoroquinolone resistance of P. aeruginosa that isolated from sputum of nosocomial pneumonia patients in Sanglah Hospital, Bali. P. aeruginosa isolated from sputum of patient that diagnosed as nosocomial pneumonia, isolates had been identified phenotypically by Vitek2 Compact system (bioMérieux, Inc., Marcy-l'Etoile - France), and then continued by genotypic detection by PCR. The susceptibility testing of P. aeruginosa isolates to Ciprofloxacin were conducted by Vitek2 Compact, whereas ExoU genes were detected by PCR. Fifty-three P. aeruginosa isolates were identified in this study, in which 35 isolates (66.1\%) had ExoU gene and 22 isolates (41.5\%) were resistant to Ciprofloxacin. Based on nosocomial pneumonia type, the highest proportion of isolates genotipically ExoU+ and phenotypically Ciprofloxacin were on VAP group accounted for 57.1\% and 54.5\%, respectively. Chi-square analysis showed significant correlation between Ciprofloxacin resistance and ExoU gene $(p=0.001)$. As a conclusion, the positivity of ExoU+ isolates were more likely found in Ciprofloxacin resistant group. (FMI 2018;54:129-135)
\end{abstract}

Keywords: Pseudomonas aeruginosa; fluoroquinolone; ExoU; nosocomial pneumonia; sputum clinical isolates

Correspondence: I Wayan Agus Gede Manik Saputra, Bali Provincial Health Office, Bali, Indonesia. Email: gedemaniksaputra@gmail.com

\section{INTRODUCTION}

Nosocomial pneumonia is a nosocomial infection or health care-associated infections (HAIs) which consist of ventilator associated pneumonia (VAP), hospital acquired pneumonia (HAP) dan healthcare-associated pneumonia (HCAP) (Kollef et al 2005, Tumbarello et al 2013). Nosocomial pneumonia is the second most noso- 
comial infection in United States, in relation to increase of morbidity, mortality and hospital costs. Nosocomial pneumonia in United States occured in 5-15 cases every 1000 hospitalized patients and 6-21 times higher in patients with mecanical ventilator (Fishman 2013).

About 20\% nosocomial cases in ICU caused by Pseudomonas aeruginosa (Gaynes and Edwards, 2005). ExoU is one of the effector proteins in addition to ExoS, ExoT and ExoY of type III secretion system (TTSS) $P$. aeruginosa. The function of TTSS is to inject toxin directly to cytoplasm eukaryote cell by using translocation needle-like apparatus (Hauser 2009, Sawa 2014). Previous research in animal showed that exoenzyme U ( ExoU) has the most important role in lung epithelial damage in pneumonia pathogenesis (Le Berre et al 2011).

ExoU is a cytotoxin which has a phospholipase A2 activity that impaired phospholipid membrane then destruct the function of the cell (Diaz \& Hauser 2010, Hauser 2009). ExoU can interferes macrophages in phagocytosis and impaired epithelial barrier so that bacteria can disseminate into host (Hauser 2009, Veesenmeyer et al 2010).

Positivity genes encoding effector protein ExoU ( ExoU) varries to each $P$. aeruginosa isolates due to its strain and source of infection (Fleiszig et al 1997, Feltman et al 2001). The ExoU+ genes were detected about $25-30 \%$ from respiratory tract isolate and $40 \%$ from blood isolates (Feltman et al 2001, Roy-Burman et al 2001). Study in mice which are infected by ExoU expressed $P$. aeruginosa isolates until developed acute pneumonia showed a higher destruction of the lung tissues and mortality rate than infection caused by other effector proteins TTSS $P$. aeruginosa (Allewelt et al 2000; Shaver and Hauser, 2004). It was supported by clinical study that $P$. aeruginosa strain with ExoU expression related to worse outcome and disease severity (El-Solh et al 2008; Hsu et al 2005; RoyBurman et al 2001).

$P$. aeruginosa is one of Gram-negative bacteria that can be easily resistant to various antibiotics. As a group of fluoroquinolone with has potent antipseudomonas activity, ciprofloxacin has the highest resistancy rate to $P$. aeruginosa among Gram-negative bacteria (Gaynes et al 2005; Neuhauser et al 2003). The prevalence of fluoroquinolone resistant (FQ-R) is increasing occured three times higher in $P$. aeruginosa isolates for the last three decades due to its overuse in therapy of community acquired pneumonia (CAP), urinary tract infection (UTI) and soft tissue and skin infection (SSI) (Neuhauser et al 2003). The global epidemiology data showed that $18.4 \%$ of $P$. aeruginosa isolate from respiratory tract is resistant to ciprofloxacin (Dalhoff, 2012). In case control study was known that FQ-R phenotype $P$. aeruginosa strains have worse clinical manifestation and three times higher mortality rate than fluoroquinolone sensitive (FQ-S) strain (Hsu et al 2005). This study aimed to determine the positivity of ExoU gene TTSS $P$. aeruginosa and fluoroquinolone resistance in clinical isolates from sputum of pneumonia nosocomial VAP HAP HCAP patients in Sanglah Hospital, Bali.

\section{MATERIALS AND METHODS}

\section{Baterial strains}

A number of 53 isolates of $P$. aeruginosa were obtained from sputum of nosocomial pneumonia (VAP, HAP and HCAP) patients between April 2016 and Pebruary 2017. The sputum isolates were originated from ICU and nonICU wards in Sanglah Hospital Bali. Isolates were collected in Clinical Microbiology Laboratory Sanglah Hospital in -800C, while DNA isolation and PCR were done in Microbiology Laboratory Faculty of Medicine, Udayana University Denpasar, Bali.

\section{Bacterial re-growth and DNA extraction}

Stock isolates were kept in TSB and glycerol 50\% solutions, then were stored in -800C. P. aeruginosa bacteria were re-cultured on Nutrient agar medium, incubated at 35 $\pm 20 \mathrm{C}$ for 18-24 hours. As many as 5-10 pure colonies were added into $100 \mu \mathrm{TE}$ solution $\mathrm{pH}$ 8.0 and mixed thoroughly. Briefly, the bacteria suspension were boiled at $100^{\circ} \mathrm{C}$ for 10 minutes, then the tube were chilled for 1-3 minutes. The suspension were centrifuged at $8000 \mathrm{~g}$ for 1 minute. The supernatan obtained was used as DNA template for PCR.

\section{PCR for detection of Pseudomas aeruginosa specific gene and ExoU gene}

PCR was performed to amplify the $16 \mathrm{~S}$ rRNA of $P$. aeruginosa and ExoU gene. The oligonucleotide primer for $16 \mathrm{~S}$ rRNA $P$. aeruginosa were, forward 5'-CAA AAC TAC TGA GCT AGA GTA CG-3 and reverse 5'TAA GAT CTC AAG GAT CCC AAC GGC T-3' (Matsuda et al 2007) and oligonucleotide primer for ExoU were, forward 5'- CCG TTG TGG TGC CGT TGA AG -3' and reverse 5'- CCA GAT GTT CAC CGA CTC GC-3' (Ajayi et al 2003). Mix PCR for PCR $16 \mathrm{~S}$ rRNA $P$. aeruginosa consist of $12.5 \mu \mathrm{l}$ Go Taq ${ }^{\circledR}$ Green Master Mix Promega, primers with each concentration $0.8 \mu \mathrm{M}, 2 \mu \mathrm{l}$ template DNA and ddH2O until final volume $25 \mu \mathrm{l}$. The PCR cycle was run as follows: initial denaturation at $95^{\circ} \mathrm{C}$ for $3 \mathrm{~min} ; 35$ cycles of $95^{\circ} \mathrm{C}$ for $1 \mathrm{~min}, 55^{\circ} \mathrm{C}$ for $1 \mathrm{~min}, 72^{\circ} \mathrm{C}$ for $90 \mathrm{~s}$; and a final 
extension step at $72^{\circ} \mathrm{C}$ for $7 \mathrm{~min}$. Mix PCR for ExoU consist of $12.5 \mu \mathrm{l}$ Go Taq ${ }^{\circledR}$ Green Master Mix Promega, forward and reverse primer each concentration 0.4 $\mu \mathrm{M}, 1 \mu \mathrm{l}$ template DNA and $\mathrm{ddH} 2 \mathrm{O}$ until final volume $25 \mu$. The PCR cycle was run as follows: initial denaturation at $95^{\circ} \mathrm{C}$ for $3 \mathrm{~min} ; 36$ cycles of $95^{\circ} \mathrm{C}$ for 15 $\mathrm{s}, 54^{\circ} \mathrm{C}$ for $15 \mathrm{~s}, 72^{\circ} \mathrm{C}$ for $1 \mathrm{~min}$; and a final extension step at $72^{\circ} \mathrm{C}$ for $1 \mathrm{~min}$. The amplicon was electrophoresed into $1,5 \%$ agarose gel, stained with $1 \mu \mathrm{lgel}$ red at 50 volt for $60 \mathrm{~min}$.

\section{Fluoroquinolone resistance}

The antimicrobial susceptibility testing (AST) of fluoroquinolone against $P$. aeruginosa were conducted by Vitek2 Compact system (bioMérieux, Inc., Marcyl'Etoile - France) with breakpoint of sensitive (MIC $=1$ $\mu \mathrm{g})$, intermediate $(1<\mathrm{MIC}<4 \mu \mathrm{g})$ and resistant $(\mathrm{MIC}=4$ $\mu \mathrm{g})$. The intermediate and resistant were grouped into resistant cathegory (Patel et al 2015).

\section{RESULTS}

Fifty-three isolates were detected phenotypically and genotipically as a $P$. aeruginosa bacterium. In this study phenotype detection were performed by automated
Vitek2 compact system (bioMérieux, Inc., Marcyl'Etoile, France), while genotype detection by amplifying $16 \mathrm{~S}$ rRNA $P$. aeruginosa gene (Fig. 1).

\section{Co-infection bacteria in nosocomial pneumonia caused by $P$. aeruginosa}

There were two bacterial species identified from 15 isolates $(15.3 \%)$ on culture media, that were decided as coinfection in nosocomial pneumonia. The most common bacteria that cause coinfection was Klebsiella pneumonia ssp pneumoniae (7/46\%), followed by Acinetobacter baumanii (4/27\%) and Escherichia coli $(2 / 13 \%)$. Other bacteria that were identified as a cause of coinfection were Enterobacter aerogenes and Providencia rettgeri (1 isolate each/7\%) (Fig. 2).

\section{Ciprofloxacin resistance of $\boldsymbol{P}$. aeruginosa}

Based on antimicrobial susceptibility testing to $P$. aeruginosa isolates from nosocomial pneumonia patients, 31 isolates $(58.5 \%)$ were sensitive, while 22 isolates $(41.5 \%)$ were resistant to ciprofloxacin (table 1). The group with the highest proportion of Ciprofloxacin resistant were in VAP group $(54.5 \%)$, whilst HCAP and HAP only accounted for $27.3 \%$ dan $18.2 \%$ (Table 1 ).

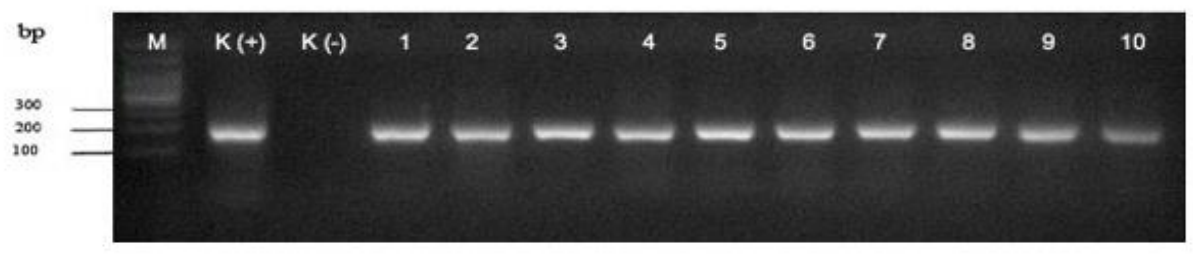

Fig. 1. Molecular detection of 16S rRNA $P$. aeruginosa gene from sputum clinical isolates from nosocomial pneumonia patients. Lane $1(\mathrm{M})=$ Marker $($ Marker gene ruler 100 bp DNA ladder $($ Geneaid®)), Lane $2(\mathrm{~K}(+)=$ positive control 16S rRNA $P$. aeruginosa (215 bp), Lane $3 \mathrm{~K}(-)=$ negative control, Lane $4-13(1-10)=$ sample number 1 10 (215bp).

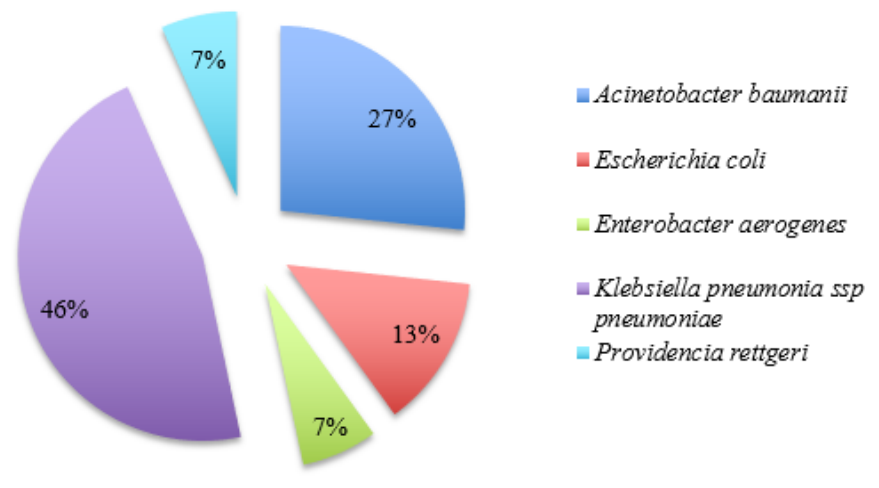

Fig. 2. Proportion of coinfection bacteria in nosocomial pneumonia caused by $P$. aeruginosa. 
Table 1. ExoU gene and Ciprofloxacin Resistant from Pseudomonas aeruginosa Isolates in Sanglah Hospital Period April 2016-February 2017

\begin{tabular}{lcc}
\hline \multicolumn{1}{c}{ Type of pneumonia } & Ciprofloxacin-resistant & ExoU $^{+}$ \\
\hline VAP $(28)$ & $\mathrm{n}(\%)$ & $\mathrm{n}(\%)$ \\
HAP $(9)$ & $12(54.5)$ & $20(57.1)$ \\
HCAP $(16)$ & $4(18.2)$ & $5(14.3)$ \\
\hline Total & $6(27.3)$ & $10(28.6)$ \\
& $22(41.5)$ & $35(66.1)$ \\
& & $(\mathrm{p}=0.001)$ \\
\hline
\end{tabular}

Table 2. Proportion of Ciprofloxacin resistance with MDRO phenotype

\begin{tabular}{|c|c|c|c|c|c|c|c|}
\hline & & \multicolumn{3}{|c|}{$\begin{array}{c}\text { MDRO } \\
18(81.8) \\
\end{array}$} & \multicolumn{3}{|c|}{$\begin{array}{c}\text { Non-MDRO } \\
4(18.2) \\
\end{array}$} \\
\hline & & VAP & HAP & HCAP & VAP & HAP & HCAP \\
\hline Ciprofloxacin & $\mathrm{n}$ & 11 & 2 & 5 & 1 & 2 & 1 \\
\hline Resistant $(\mathrm{n}=22)$ & $\%$ & 61.1 & 11.1 & 27.8 & 25 & 50 & 25 \\
\hline
\end{tabular}

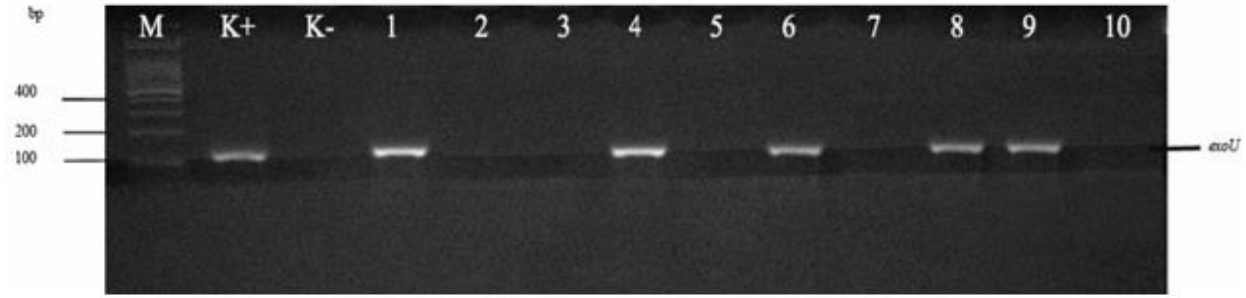

Fig. 3. Molecular detection of ExoU gene $P$. aeruginosa from sputum clinical isolates nosocomial pneumonia. Lane 1 $(\mathrm{M})=$ Marker $(100 \mathrm{bp}$ DNA ladder $($ Geneaid $®))$, Lane $2(\mathrm{~K}(+)=$ positive control ExoU gene $(134 \mathrm{bp})$, Lane 3 $\mathrm{K}(-)=$ negative control, Lane 4-13 (1-10) = sample number 1-10 (134 bp).

\section{Detection of ExoU gene}

Detection of ExoU gene as an encoding efector protein exoenzyme U TTSS $P$. aeruginosa used uniplex PCR (Fig. 3). The proportion of ExoU gene on this study were $66.1 \%$ ( 5 isolates). Based on nosocomial pneumonia type, the highest proportion of ExoU gene was on VAP 57.1\% (20 isolates), whereas the proportion in HAP and HCAP were $14.3 \%$ (5 isolates) and 28.6\% (10 isolates), respectively.

\section{DISCUSSION}

Nosocomial pneumonia mostly caused by Gram-negative rods $(65.9 \%)$ and $P$. aeruginosa is known as the most frequent bacterial causative agent (18.1\%) (Gaynes \& Edwards, 2005). Nosocomial pneumonia caused by $P$. aeruginosa correlates with increasing of morbidity, length of hospital stay, cost and mortality rate (Vincent et al 2006). As the most important effector protein in pneumonia pathogenesis, ExoU has a phospholipase A2 (PLA2) activity that impaired phagocy- tosis and cause epithelial damage (Hauser 2009, Veesenmeyer et al 2010). The PLA2 produced by ExoU similar to mammalian PLA2 enzyme that has cytotoxic activity to eukaryote cells (Hurley \& McCormick, 2008). PLA2 activity can also impaired surfactan's function in the lungs due to phos-pholipid hydrolysis (Kirschnek \& Gulbins 2006).

ExoU is one of effector protein of TTSS $P$. aeruginosa that really contribute to epithelial damage of lung in pneumonia (Le Berre et al 2011). Infections caused by $P$. aeruginosa that express ExoU strongly related to severity of pneumonia with its higher complication and mortality rate (Sato \& Frank, 2004). On this study, proportion of ExoU gene encoding ExoU was 66,1\%. Wong-Beringer et al (2008) and Roy-Burman et al (2001) showed that proportion of ExoU gene from sputum specimen between 23-30\%. Feltman et al (2001) showed that proportion of ExoU gene from lower respiratory tract specimens was $17.5 \%$. Lomholt et al (2001) showed that proportion of ExoU from all specimens and sputum were $34 \%$ and $4 \%$, respectively. A higher proportion of ExoU showed by Cho et al (2014), 56.8\%. 
The high proportion of ExoU gene due to its clonality of isolates and pathogen (Roy-Burman et al 2001; Zhu et al 2006). The high proportion of ExoU+ gene can be obtained by horizontal gene transfer (HGT) mechanism that indicate not only highly virulence $P$. aeruginosa strain but also its ability to colonize and survive in environment (Wolfgang et al 2003).

ExoU were expressed during acute phase of infection and contribute to severe pneumonia due to phagocytosis impairment. Thus can lead $P$. aeruginosa persist in lungs caused local immunosuppression subsequently facilitate coinfection by other lower pathogenicity bacteria (Diaz et al 2008; Sawa et al 2014). On this study showed patients with coinfection and Klebsiella pneumonia ssp pneumoniae as the most common bacteria (7 isolates/46\%). A study from Tumbarello et al (2013) found that Acinetobacter baumanii as the most causes of coinfection (7 isolat/6.4\%). Based on previous studies, pneumonia caused by $P$. aeruginosa that expressed ExoU not only induce serious infection but also polimicrobial infection (Diaz et al 2008; Sawa et al 2014).

Resistance of $P$. aeruginosa to ciprofloxacin tend to increase in few decades due to over prescribe for empirical therapy (Dalhoff 2012, Neuhauser et al 2003). On this study ciprofloxacin resistant was found $41.5 \%$. El-Solh et al (2012) showed that ciprofloxacin resistant in $P$. aeruginosa respiratory isolates was $59 \%$. The lower proportion of ciprofloxacin resistant from lower respiratory isolates was found by Zhanel et al (2010) accounted for $18.4 \%$. From several clinical studies showed that patients with $P$. aeruginosa infections tend to have worse clinical outcome if the isolates express ExoU and has fluoroquinolone resistant phenotype (Hsu et al 2005; Roy-Burman et al 2001).

On this study, ciprofloxacin resistant isolates with MDRO phenotype were very high if compared to NonMDRO (81.8\% vs $18.2 \%)$. A retrospective multicenter study by Micek et al (2015) indicate that nosocomial pneumonia prevalence caused by MDRO phenotype $P$. aeruginosa was $30.5 \%$. Based on that finding, the most common risk factors impact to MDRO pnenotype are history of antibiotic in 30 days, chronic obstructive pulmonary disease and diabetes mellitus. MDRO phenotype were more predominant in ICU patients (44.4\%) than Non-ICU patients (20\%) (Tumbarello et al 2013). Hsu et al (2005) showed that MDRO phenotype has 12.6 times higher fluoroquinolone resistant. Pneumonia caused by MDRO phenoytype $P$. aeruginosa altered failure therapy and impact to high mortality rate (Sawa 2014). Fluoroquinolone resistant strain $P$. aeruginosa conferred cross resitance to other antipseudomonas groups that was underlying MDRO
(Neuhauser et al 2003). Efflux pump overexpression (EPO) is a mechanism involved in MDRO phenotype $P$. aeruginosa. The occurance of EPO due to mutation in genes nalB, nfxB dan nfxC. Mutation of those genes then accomodate various substrate that structural unrelated from cytoplasma to periplasma space of bacteria subsequently conferred resistance to various class of antibiotics (Hancock 1998, Poole 2000).

Fluoroquinolone resistant can be occured by over exposure of antibiotic that leads to chromosome recombination which encode resistance and virulence genes (Fitzgerald et al 2001). The mutation of gyrA gene in resistance mechanism in fluoroquinolone conferred to DNA supercoiling that lead to bacteria virulence gene expression (Dorman et al 1990, Dorman 1990). Mutation in gyrA gene causes impairment of negative supercoiling DNA that lead the resistance of fluoroquinolone then induce expression of gene encoding effector protein TTSS $P$. aeruginosa (Wong-Beringer, 2008). Tran et al (2011) showed that gyrA mutation in codon Ile83Thr and parcC mutation in codon Leu87Ser correlate with expression of gene encoding TTSS $P$. aeruginosa.

To date, the precise mechanism how gene encoding effector protein TTSS $P$. aeruginosa being expressed due to gyrA mutation is not well documented. Generally regulation to expression genes encoding effector protein consist of intrinsic and extrinsic regulation. ExsA has an important role in central regulator in intrinsic regulation and Vfr (Virulence factor regulator) as an extrinsic regulation (Diaz, King and Yahr, 2011). Chen et al (2016) showed that an enzyme called oligoribonuclease (Orn) involved in TTSS $P$. aeruginosa expression by contact dependent between bacteria and host cell. That enzyme was conserved in bacteria which has a 3'-5' exonuclease activity that break 2-5-nt RNA (nanoRNA) to mononucleotide. If Orn decreases, there will increase of nanoRNA and cyclic-di-GMP (C-di-GMP) that can decrease expression TTSS $P$. aeruginosa (Chen et al 2016, Chen et al 2017). C-di-GMP altered the amount of cAMP levels that induce expression of TTSS genes by cAMP reseptor protein $\mathrm{Vfr}$ (Chen et al 2016).

If DNA damage occured due to gyrA mutation will lead to SOS response (Wu \& Jin 2005). SOS response is a response occur to cell that encountered DNA damage or impaired DNA replication subsequently impact to cell cleavage and increase of DNA repair and mutagenesis (Little \& Mount 1982). Chen and colleagues (2017) showed that in Orn mutant there would be up-regulation to genes involved in SOS response that initiate DNA damage. Based on that study can be assumed that role of Orn in DNA damage due to gyrA mutation in fluoro- 
quinolone resistant isolate will induce expression of TTSS $P$. aeruginosa genes.

\section{CONCLUSION}

In nosocomial pneumonia (VAP, HAP and HCAP), the positivity of ExoU+ gene were more likely found in Ciprofloxacin resistant group than in Ciprofloxacin sensitive group. Based on nosocomial type, the highest proportion of isolates genotypically ExoU+ and phenotypically Ciprofloxacin resistant were found in VAP group accounted for $57.1 \%$ and $54.5 \%$, respectively. There was significant correlation between ciprofloxacin resistance and ExoU gene $(\mathrm{p}=0.001)$.

\section{ACKNOWLEDGMENT}

I would like to thank to all staff in Clinical Microbiology Laboratory in Sanglah Hospital, Bali and Microbiology Laboratory of Faculty of Medicine, Udayana University, Denpasar, Bali, especially Wahyu Hidayati, SKM and Dianti Violentina who has assisted during the research process at the laboratory.

\section{REFERENCES}

Ajayi T, Allmond LR, Sawa T, Wiener-kronish JP (2003). Single-nucleotide-polymorphism mapping of the Pseudomonas aeruginosa type III secretion toxins for development of a diagnostic multiplex PCR. J. Clin Microbiol 41, 3526-31

Allewelt M, Coleman FT, Grout M, Priebe GP, Pier GB (2000). Acquisition of expression of the Pseudomonas aeruginosa ExoU cytotoxin leads to increased bacterial virulence in a murine model of acute pneumonia and systemic spread. Infect. and Immun 68, 3998-4004

Chen G, Zhao Q, Zhu F, Chen R, Jin Y, Liu C, Pan X, Jin S, Wu W, Cheng Z (2016). Oligoribonuclease is required for the type III secretion system and pathogenesis of Pseudomonas aeruginosa. Microbiol. Research 188, 90-96

Chen F, Chen G, Liu Y, Jin Y, Cheng Z, Liu Y, Yang L, Jin S, Wu W (2017). Pseudomonas aeruginosa oligoribonuclease contributes to tolerance to ciprofloxacin by regulating pyocin biosynthesis. Antimcrob. Agents Chemother. doi:10.1128/AAC.0225616.

Cho HH, Kwon KC, Kim S, Koo SH (2014). Correlation between virulence genotype and fluoroquinolone resistance in carbapenem-resistant Pseudomonas aeruginosa. Ann. Lab. Med 34, 286-92

Dalhoff A (2012). Global fluoroquinolone resistance epidemiology and implictions for clinical use. Interdis. Persp. Infect. Dis 2012, 1-37
Diaz MH, Hauser AR (2010). Pseudomonas aeruginosa cytotoxin ExoU is injected into phagocytic cells during acute pneumonia. Inf. and Immun 78, 1447-56

Diaz MR, King JM, Yahr TL (2011). Intrinsic and extrinsic regulation of type III secretion gene expression in Pseudomonas aeruginosa. Front. in Microbiol 2, 1-10

Diaz MH, Shaver CM, King JD, Musunuri S, Kazzaz JA, Hauser AR (2008). Pseudomonas aeruginosa induces localized immunosuppression during pneumonia. Infect Immun 76, 4414-21

Dorman CJ (1990). DNA supercoiling and environmental regulation of gene expression in pathogenic bacteria. Infect Immun 59, 745-49

Dorman CJ, Bhriain NN, Higgins, CF (1990). DNA supercoiling and environmental regulation of virulence gene expression in Shigella flexneri. Nat 344, 789-91

El-Solh AA, Akinnusi ME, Wiener-Kronish JP, Lynch SV, Pineda LA, Szarpa K (2008). Persistent infection with Pseudomonas aeruginosa in ventilator associated pneumonia. Am. J. Respir Crit Care Med 178, 513-19

El-Solh AA, Hattemer A, Hauser AR, Alhajhusain A, Vora H (2012). Clinical outcomes of the type III Pseudomonas aeruginosa bacteremia. Crit Care Med 40, 1157-63

Feltman H, Jain M, Peterson L, Schulert G, Khan S, Hauser AR (2001). Prevalence of type III secretion genes in clinical and environmental isolates of Pseudomonas aeruginosa. Microbiol 147, 2659-69

Fishman JA (2013). Nosocomial pneumonia. In Tobergte DR, and Curtis S. Fishman's Pulmonary Disease and Disorders. 4th ed. United States, McGraw Hill, 2273-90

Fleiszig SMJ, Evans DJ, Do N, Vallas V, Shin S, Mostov KE (1997). Epithelial cell polarity affects susceptibility to Pseudomonas aeruginosa invasion and cytotoxicity. Infect. and Immun 65, 2861-67

Gaynes R, Edwards JR (2005). Overview of nosocomial infections caused by gram-negative bacilli. Clin. Infect. Dis 41, 848-54

Hauser AR (2009). The type III secretion system of Pseudomonas aeruginosa: infection by injection. Nat. rev. Microbiol 7, 654-65

Hancock REW (1998). Resistance mechanisms in Pseudomonas aeruginosa and other nonfermentative Gram-negative Bacteria. Clin. Inf. Dis 27, S93-9

Hsu DI, Okamoto MP, Murthy R, Wong-Beringer A (2005). Fluoroquinolone-resistant Pseudomonas aeruginosa: Risk factors for acquisition and impact on outcomes'. J. Antimic. Chem. 55, 535-41

Hurley BP, McCormick BA (2008). Multiple roles of phospholipase A2 during lung infection and inflammation. Infect. and Immun 76, 2259-72

Kollef MH, Shorr A, Tabak YP, Gupta V, Liu LZ, Johannes RS (2005). Epidemiology and outcomes of 
health-care-associated pneumonia: results from a large us database of culture-positive pneumonia. Chest $\mathbf{J}$ 128, 3854-3862

Kirschnek S, Gulbins, E (2006). Phospholipase A2 functions in Pseudomonas aeruginosa - induced apoptosis. Inf. \& Immun 74, 850-60

Le Berre R, Nguyen S, Nowak E, Kipnis E, Pierre M, Quenee L, Ader F, Lancel S, Courcol R, Guery BP, Faure K (2011). Relative contribution of three main virulence factors in Pseudomonas aeruginosa pneumonia. Crit. care med 39, 2113-20

Little JW, Mount DW (1982). The SOS regulatory system of Escherichia coli. Cells. 29, 11-22

Lomholt JA, Poulsen K, Kilian M (2001). Epidemic population structure of Pseudomonas aeruginosa: Evidence for a clone that is pathogenic to the eye and that has a distinct combination of virulence factors. Inf \& Immun 69, 6284-95

Matsuda K, Tsuji H, Asahara T, Kado Y, Nomoto K (2007). Sensitive quantitative detection of commensal bacteria by rRNA-targeted reverse transcription-PCR. Appl. and Env. Microbiol 73, 32-39

Micek ST, Wunderink RG, Kollef MH, Chen C, Rello J, Chastre J, Antonelli M, Welte T, Clair B, Helmut O, Calbo E, Torres A, Menichetti F, Schramm GE, Vandana M (2015). An international multicenter retrospective study of Pseudomonas aeruginosa nosocomial pneumonia: impact of multidrug resistance. Crit. Care 19, 219

Neuhauser MM, Weinstein RA, Rydman R, Danziger LH, Karam G, Quinn JP (2003). Antibiotic resistance among gram-negative bacilli in US intensive care units: implications for fluoroquinolone use. JAMA 289, 885-88

Patel JB, Cockerill F, Bradford PA, Eliopoulos GM, Hindler JA, Jenkins SG, Lewis JS, Limbago B, Miller LA, Nicolau DP, Mair P, Swenson JM, Traczewski $\mathrm{MM}$, Turnidge JD, Weinstein $\mathrm{M}$, and Zimmer BL (2015). M100-S25 performance standards for antimicrobial

Roy-Burman A, Savel RH, Racine S, Swanson BL, Revadigar NS, Fujimoto J, Sawa T, Frank DW, Wiener-Kronish JP (2001). Type III protein secretion is associated with death in lower respiration and systemic Pseudomonas aeruginosa infections. J. Infect Dis 2001, 1767-74

Sawa T (2014). The molecular mechanism of acute lung injury caused by Pseudomonas aeruginosa: from bacterial pathogenesis to host response. J. Intens. Care 2,10

Sawa T, Shimizu M, Moriyama K, Wiener-Kronish JP (2014). Association between Pseudomonas aerugino$s a$ type III secretion, antibiotic resistance, and clinical outcome: A review. Crit. Care 18, 668
Sato H, and Frank DW, 2004. ExoU is a potent intracellular phospholipase. Mol. Microbiol 53, 127990

Shaver CM, Hauser AR (2004). Relative contributions of Pseudomonas aeruginosa ExoU, ExoS, and ExoT to virulence in the lung. Infect. \& Immun 72, 6969-77

Tran QT, Nawas MS, Deck J, Foley S, Nguyen K, Cerniglia CE (2011). Detection of type III secretion system virulence and mutations in gyrA and ParC genes among quinolone-resistant strain of Pseudomonas aeruginosa from imported shrimp. Foodborne Path. \& Dis 8, 451-53

Poole K (2000). Efflux mediated resistance to fluoroquinolone in Gram-negative bacteria. Antimic Agents \& Chemoth 44, 2233-41

Tumbarello M, De Pascale G, Trecarichi EM, Spanu T, Antonicelli F, Maviglia R, Pennisi MA, Bello G, Antonelli M (2013). Clinical outcomes of Pseudomonas aeruginosa pneumonia in intensive care unit patients. Intens. Care Med 39, 682-92

Veesenmeyer J, Hauser A, Lisboa T, Rello J (2010). Pseudomonas aeruginosa virulence and therapy: evolving translational strategies. Crit Care Med 37, 1777-86

Vincent JL, Sakr Y, Sprung CL, Ranieri VM, Reinhart K, Gerlach H (2006). Sepsis occurrence in acutely ill patients investigators. Sepsis in European intensive care units: results of the SOAP study. Crit Care Med 34, 344-53

Wolfgang MC, Kulasekara BR, Liang X, Boyd D, Wu K, Yang Q, Lory S (2003). Conservation of genome content and virulence determinants among clinical and environmental isolates of Pseudomonas aeruginosa. Natl Acad of Sci USA 100, 8484-9

Wong-Beringer A, Wiener-Kronish J, Lynch S, Flanagan J (2008). Comparison of type III secretion system virulence among fluoroquinolone-susceptible and -resistant clinical isolates of Pseudomonas aeruginosa. J. Soc. of Clin. Microbiol and Infect. Dis. CMI, 330-336

Wu W, Jin S (2005). PtrB of Pseudomonas aeruginosa suppresses the type III secretion system under the stress of DNA damage. J. of Bacteriol 187, 6058-68

Zhanel GG, Decorby M, Adam H, Mulvey MR, Mccracken M, Nichol KA, Hoban DJ (2010). Prevalence of antimicrobial-resistant pathogens in canadian hospitals: Results of the canadian ward surveillance study (CANWARD 2008). Antimic Agent \& Chemoth 54, 4684-93

Zhu H, Conibear TCR, Bandara R, Aliwarga Y, Stapleton F, Willcox MDP (2006). Type III secretion system-associated toxins, proteases, serotypes, and antibiotic resistance of Pseudomonas aeruginosa isolates associated with keratitis. Curr Eye Research 31, 297-306 